\title{
Release Within Confinement: An Alternative Proposal for Managing the Masturbation of Incarcerated Men in U.S. Prisons
}

\author{
Sam D. Hughes \\ University of California, Santa Cruz (USA) \\ sadhughe@ucsc.edu
}

\begin{abstract}
Policies regarding masturbation among incarcerated men vary throughout the United States. To describe the state of these policies, a systematic review of prison masturbation policies was conducted. The review revealed that masturbation among incarcerated men is banned in most U.S. prisons (sometimes in all cases, and other times only when it is intended to disturb others, and/or is public). Furthermore, many states' Departments of Corrections have made these policies difficult for the public to identify. Prison masturbation bans have been defended on the grounds that they reduce STI transmission, help maintain order, prevent hostile work environments for female prison staff, assist in prison rape prosecutions, and assist in rehabilitating incarcerated people. By reviewing the available social science and endocrinological research on masturbation, those justifications are found to have minimal basis in scientific evidence. Conversely, the evidence does suggest the masturbation bans could potentially be linked with higher rates of violence, rape, exploitation, sex offender recidivism, insomnia, stress, depression, and suicide. Instead of being rooted in evidence, bans on prison masturbation seem to be primarily motivated by sex-negativity and the desire to retributively punish incarcerated people. To alleviate these harms, this article suggests allowing incarcerated men to masturbate within specifically identified circumstances, and/or to lessen existing punishments for masturbation. Potential problems with the implementation of the suggested policy are discussed, and a call is made to make inmate handbooks, which contain most of these policies, available to the public. Unique opportunities for penological and sexological research are identified.
\end{abstract}

\section{Introduction}

In 2006, the Eleventh Circuit Court of Appeals took up a unique case. Angela Harris, a female correctional officer in Georgia was sued by a man incarcerated in prison on the grounds that her behavior toward him violated the cruel and unusual punishment clause of the Eighth Amendment to the U.S. Constitution. While the man was held in solitary confinement, Harris allegedly forced him to strip and masturbate for her entertainment, threatened to deny him food and, ironically, threatened to file a disciplinary report that he had masturbated in front of her if he did not comply with her demands (Boxer X v. Harris, 2006). Surprisingly, over a scathing dissent, the court decided to affirm the lower court decision to dismiss the case, concluding,

On the facts as alleged in the complaint, however, Boxer has failed to meet this standard. We conclude that a female prison guard's solicitation of a male prisoner's manual masturbation, even under the threat of reprisal, does not present more than de minimis injury. Accordingly, we affirm the dismissal of Boxer's claim under the Eighth Amendment. (Boxer X v. Harris, 2006) 
This case, which has been cited more than 100 times in subsequent decisions, is representative of the conflicted nature of attitudes toward prison masturbation. On the one hand, masturbation is officially banned in most U.S. prisons (B. Smith, 2006; see systematic review below) on the justification that masturbation, just like any other form of sexual expression, is harmful to incarcerated people and the healthy functioning of the prison environment (Cusack, 2014). Yet, on the other hand, being forced to masturbate on the threat of starvation is not considered by the criminal justice system to be harmful enough to incarcerated people to constitute a serious injury, especially if the person being forced to masturbate is male (Coker, 2014). Instead, it is thought of as trivial. This conflicted attitude toward masturbation as harmful/not harmful and important/trivial warrants further investigation.

Thus, in this article, I will report the methods and results of a systematic analysis of publicly available polices regarding masturbation by males in U.S. prisons. After establishing the current state of these policies, I will then review the historical context that led up to the ban and investigate the empirical literature and case law that exists on the masturbation of incarcerated men. Next, I will scrutinize the justifications employed to defend the ban on masturbation in U.S. prisons and contend that the ban results in serious negative consequences for both incarcerated people and the prison environment as a whole. As an alternative, I will lay out a new policy proposal for handling masturbation within U.S. prisons. Finally, I will anticipate and respond to potential objections to that proposed policy.

\section{Systematic Review Method}

In order to determine the current state of regulations regarding male masturbation in U.S. prisons, a systematic review of publicly available regulations was conducted. This review was undertaken by three coders using the following procedure.

First, for each state in the United States (and the District of Colombia), we accessed the jurisdiction's Department of Corrections website. We then attempted to locate a repository of policies, regulations, and/or documents regarding the running of prisons by navigating through each website. Once a repository of documents was identified, we then looked at the titles of each policy document and made a determination of whether or not the policy document would have any reasonable degree of likelihood to discuss sexuality. For each document that was determined to potentially include that subject, the document was opened, and an automated search was conducted for the words "sex*," "masturb*," "touch*," and "ejacul*." Each clause that returned a hit was evaluated for whether or not it was a clause regarding the regulation of masturbation by incarcerated men. If a regulation was identified, it was collected for use in this review.

Second, if no policies were found on the Department of Corrections website, coders then searched the University of Michigan Law School Policy Clearinghouse for inmate handbooks for each state (often only available as a result of a successful Freedom of Information Act Request) and conducted an automated search of each handbook using the same four keywords. Each clause that returned a hit was evaluated for whether or not it was a clause regarding the regulation of masturbation by incarcerated men. If a regulation was identified, it was collected for use in this review. 
Third, if no policies were found in the Policy Clearinghouse, a google search was then conducted using each of the following search terms: "[state name] doc masturbation," "[state name] doc sexual misconduct," "[state name] doc inappropriate sexual behavior," "[state name] doc ejaculation," "[state name] doc inmate handbook.” The first page of results was reviewed, and each search result was evaluated as to whether it would have any reasonable degree of likelihood to discuss prison masturbation policies. For each search result that was determined to potentially discuss the subject, an automated search of each search result's page (or attached document if the page was a link) was conducted using the same four keywords (i.e., "sex*," "masturb*," "touch*," and “ejacul*.”) Each clause that returned a hit was evaluated for whether or not it was a clause regarding the regulation of masturbation by incarcerated men. If a regulation was identified, it was collected for use in this review.

Fourth, if no policies were found at this point, a google news search was conducted using the search terms: "[state name] doc masturbation," "[state name] doc sexual misconduct," "[state name] doc inappropriate sexual behavior," "[state name] doc ejaculation.” The first two pages of results were then evaluated to determine if any of the news stories had any reasonable degree of likelihood to discuss prison masturbation policies. For a news article that was determined to potentially discuss the subject, an automated search of the news article was conducted using the same four keywords (i.e., "sex*," “masturb*," "touch*,” and “ejacul*.”) Each clause that returned a hit was evaluated for whether or not it was a clause regarding the regulation of masturbation by incarcerated men. If a regulation was identified, it was collected for use in this review.

Fifth, if a document was identified during steps two through four, the name of the document was then run through another google search to determine if a more recently updated document was publicly available. The first page of search results was then reviewed.

Finally, if no documents or policies were identified in any of the first four stages above, the state was marked as having no publicly available policy.

After the text of each policy was collected, the author conducted a conventional content analysis (Hsieh \& Shannon, 2005) to identify the potential coding categories that emerged from the text of these policies, and then coded each policy into its relevant emergent category.

\section{Systematic Review Results}

Six coding categories emerged through the conventional content analysis: (a) All Masturbation Banned, (b) All Public Masturbation Banned, (c) Public Masturbation Banned with Ambiguous Intentionality, (d) Intentional Public Masturbation Banned, (e) No Policy Publicly Available, But Likely Exists, and (f) No Policy Publicly available. Thirty-seven states plus the District of Colombia maintained some form of publicly available policy banning masturbation (see Table 1 for a summary and examples), either in all circumstances (six states), if it is seen by another person, even if not intentionally (seven states), or either ambiguously or clearly requiring that it be intentionally public (17 states). Of the remaining 13 states without a publicly available policy, three states had some form of news coverage indicating such a policy existed, despite the 


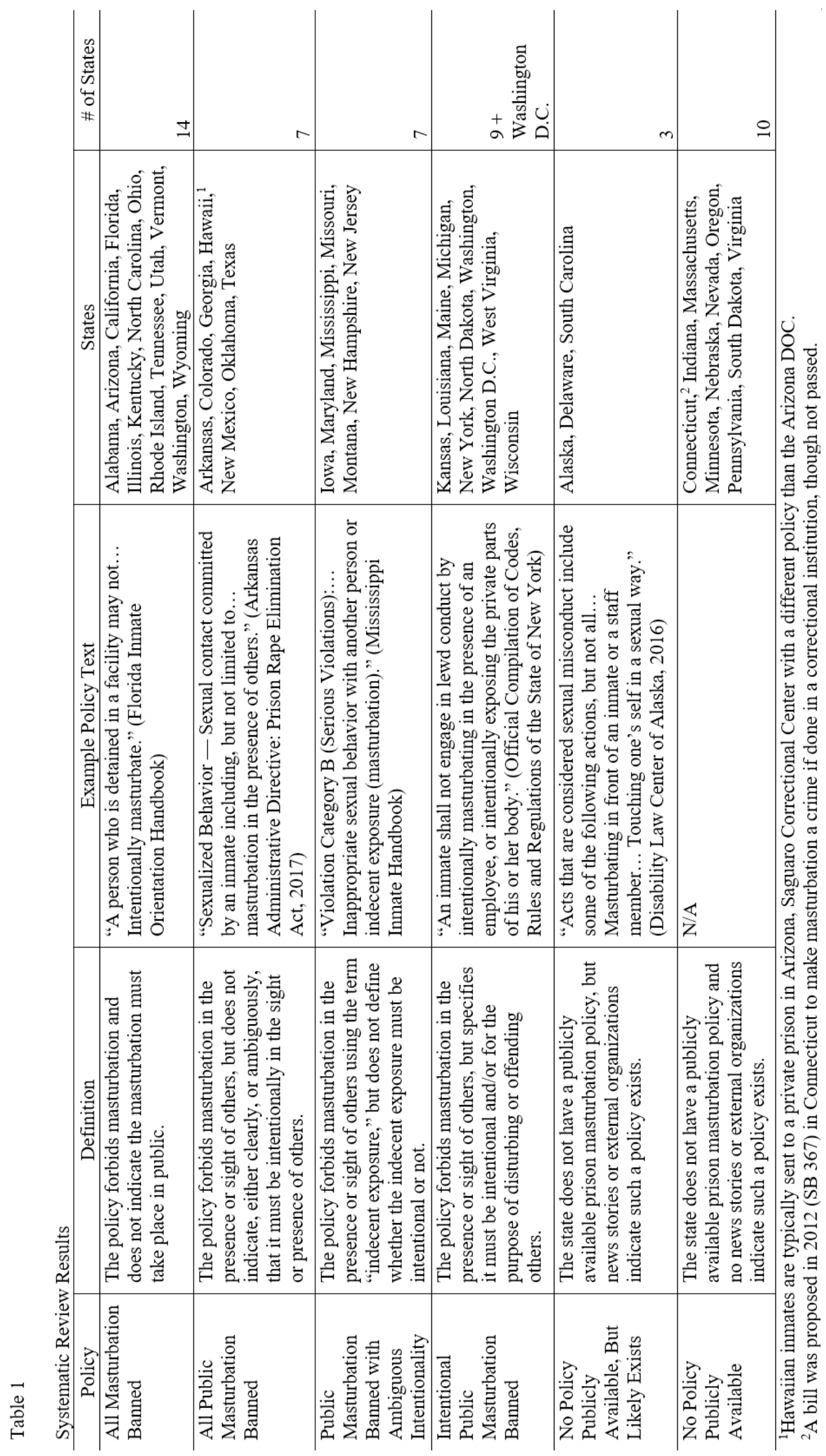


fact that it was not accessible via the systematic review process. The implications of the existence of policies that punish people for masturbating, while not being available to the public, will be discussed in the conclusion to this article. Thus, masturbation is currently banned in some form in most U.S. prisons (Cusack, 2014; McGaughey \& Tewksbury, 2002). While typically banned as part of a larger statute that prevents sexual behavior of any kind among incarcerated men, occasionally masturbation is addressed specifically within state penal codes. For example, the Texas penal code allows for masturbation within prisons only if no one else is made aware that the incarcerated man is masturbating (Stephens, 2015). However, given the nature of prisons as semi-public spaces with little to no privacy (Cusack, 2014), this kind of policy is effectively a ban on masturbation. After all, it includes a rule that says, "you will not be punished for masturbating if you do not get caught." In function, this is identical to an outright ban, since under a ban on masturbation, it is still the case that incarcerated men are not punished for masturbating if they do not get caught. Only bans that explicitly require intentionality (which appear to only exist in ten states) are distinct from an outright ban on masturbation. While such a policy has been challenged on the grounds that it constitutes cruel and unusual punishment, there is clear precedent in the case law justifying the constitutionality of a ban on prison masturbation, as it does not violate the Eighth Amendment (Rodgers v. Ohio Dept. Of Rehab. \& Corr., 1993). Consequently, these policies remain widespread and legal.

\section{Historical Context}

Putting a person into a prison environment has typically entailed depriving them of sexual relationships with people outside of the prison, historically termed the "deprivation of heterosexual relationships” by Sykes (1958, p. 70). This leads most incarcerated people to respond to that loss by masturbating as a way to cope with their sexual needs (Hensley, Tewksbury, \& Wright, 2001). Because this is such a typical strategy for coping with sexual loss as a pain of incarceration, there has been an accompanying long history of prisons seeking to prohibit the masturbation activities of incarcerated people on the basis of sex-negative assumptions. For example, prison reformers and administrators in the mid-1800s expressed explicit concern over incarcerated people engaging in "onanism," concerned that masturbation would lead to mental illness. One guard even proposed that inflicting blisters on the penises of incarcerated men would serve as a "remedy" (Rubin, 2015). In the recent past, around the 1980s, policies had become much more lenient. For example, Wooden and Parker (1982) found that as long as the masturbation was not done in a threatening manner or interfering with prison functioning, it was permitted within the prison they studied. However, since the 1980s, there may have been an increase in harsher punishments for masturbation, based on anecdotal news media coverage of harsher punishments ranging from charging men with indecent exposure to solitary confinement (Johns, 2012; Murphy, 2016). Similarly, the systematic review conducted for this article found that most states have some rule against masturbation in their prisons. So, this difference between the current treatment of masturbation and the treatment of masturbation in the recent past motivates the question: How did prisons move from fairly lenient policies toward masturbation by incarcerated men to more punitive policies (though not nearly as punitive as punishments in the far past)? To answer that question, this section will discuss two trends in the penal system that may have contributed to the maintenance of policies that explicitly ban masturbation: the rise of mass incarceration and the rise of faith-based prison programs. 


\section{Mass Incarceration}

The rise of mass incarceration may have led to tougher enforcement of laws regarding masturbation. Beginning in the 1970s, more punitive approaches to policing, such as the war on drugs, broken windows policing, three strikes rules, and the widespread adoption of mandatory minimum sentences led to significantly more crowded prisons and much higher rates of incarceration in the United States, especially in African American communities (Alexander, 2010). Both in comparison to the history of the United States, and also in comparison to all other countries in the world, the United States maintains the highest per capita rate of incarceration by far (Alexander, 2010; Glaze \& Kaeble, 2014; Haney \& Zimbardo, 1998). The higher concentrations of incarcerated African American men, in particular, also fed off of racist fears of black masculinity as aggressive, animalistic sexuality in need of control (Kunzel, 2010). At the material level, crowded prisons have very little private space, as some prisons house hundreds of incarcerated men in a single large bunk-style room, or house four people per cell. As a result, it is challenging for many incarcerated men to find spaces to masturbate without being in public to some extent. Because public masturbation is illegal (Cusack, 2014), and 37 states have some form of publicly available policy banning public masturbation among incarcerated people specifically, the lack of private spaces in many prisons due to mass incarceration may play a significant role in the serious punitive measures undertaken by prison guards to curb prison masturbation.

\section{Faith-Based Prison Programs}

Since 2001, faith-based, and especially Protestant-oriented prison rehabilitation programs have gained popularity within the U.S. prison system (Camp et al., 2006). Faith-based prison programs, especially those designed for sex offenders, often emphasize self-restraint of sexuality and "lustful urges," including avoiding masturbation as a way to gain mastery over one's demons. For example, the InnerChange Freedom Initiative, a program ruled unconstitutional by the U.S. District Court, taught that masturbation was a sin and a disease that needed to be overcome through faith and devotion to God (Americans United for Separation of Church and State v. Prison Fellowship Ministries, Inc., 2007; Cooperman, 2006; Crockett, 2012). It is likely that the ban on masturbation, in the eyes of prison officials who supported such programs, would help incarcerated people to align themselves with the goals of these faith-based programs and engage in character building through self-control.

\section{Current Status of Prison Masturbation Behaviors}

Currently, only four studies have attempted to assess the rates of masturbation within U.S. prisons, despite the dozens of studies on prison sexuality generally, and especially prison rape (McGaughey \& Tewksbury, 2002). In addition, the four studies span nearly thirty years, from 1972 to 2001 . As a result, their findings might be conflated with the idiosyncrasies of the prisons they studied, or societal changes in the prison population over that same time.

Nevertheless, given that caveat, all four studies reached the same conclusion about the rates of male prison masturbation: nearly all incarcerated men masturbate while in prison (Hensley et al., 2001; Kassebaum, 1972; Tewksbury, 1989; Wooden \& Parker, 1982). This comports with the long-standing data on men in the United States outside of prison, which reports practically all 
men having masturbated at least once, and most men having masturbated recently (Baumeister et al., 2001; Kinsey et al., 1948).

While many incarcerated men manage to avoid being seen or punished for their masturbation, by masturbating under a blanket or while a guard is not watching, those who are caught can receive serious punishment. For example, 83-year-old South Boston convict "Whitey" Bulger was caught touching his genitals alone in his cell at 3:00 a.m. and placed in solitary confinement for a full month (Murphy, 2016). But the punishment does not stop with the person who is incarcerated. Wardens have been advised to contact the non-incarcerated family members of incarcerated men who masturbate in order to pressure the family members into getting the men to stop masturbating (Bedard, 2011). Even in innocuous cases, men are sometimes sentenced to additional time in prison. For instance, Terry Lee Alexander of Florida was caught masturbating in his cell by himself when a female sheriff witnessed the act from 100 feet away in a control tower. When the state decided to press charges of indecent exposure against him, the sheriff even acknowledged that most incarcerated people masturbate (Batty, 2007). He was found guilty and sentenced to two additional months in prison. Given the harsh treatment of incarcerated men for masturbation, there is a significant burden to justify the severe punishment inflicted upon them.

\section{Justification for the Ban on Masturbation}

Because prison masturbation is so understudied (McGaughey \& Tewksbury, 2002) as well as because masturbation generally has been stigmatized (Rosewarne, 2014; Soble, 1997), very little has been written to justify the ban on prison masturbation. Only one academic article has been written explicitly defending it (Cusack, 2014). Nevertheless, the following five justifications seem to represent the primary arguments made by defenders of the ban on masturbation.

\section{STI Transmission}

Masturbation has long been considered as an alternative safer sex practice to prevent STI transmission in the general population. However, within prisons, it has been implicated, without evidence, to be associated with STI transmission by the court case that upheld the right of prisons to ban the masturbation of incarcerated people (Rodgers v. Ohio Dept. Of Rehab. \& Corr., 1993). Because semen can be a carrier for certain types of sexually transmitted infections (STIs), including Human Immunodeficiency Virus (HIV), some defenders of the masturbation ban argue that the ejaculation of semen through masturbation could spread the infection. Thus, it is justifiable to ban masturbation in the name of preventing STI transmission.

\section{Order}

The other justification for the ban to come out of Rodgers $v$. Ohio is the need to maintain order within a prison. The argument is usually articulated as follows: Prisons typically contain few to no areas of privacy, so masturbation in prison constitutes masturbation in public (Cusack, 2014). To prevent public masturbation, and the disorder and conflict it can cause between 
incarcerated people, therefore, it is justified to prevent masturbation. Prison authorities have also cited order as a justification in the popular press (e.g., Johns, 2012).

\section{Hostile Work Environment}

As policies regarding the hiring of prison guards have become less sexist, there has been an uptick in the number of female prison guards working in male prisons. As a result of a more gender-diverse prison staff, there has also been an increase in female guards witnessing incarcerated men masturbate and suing the prison for creating a hostile work environment (e.g., Freitag v. Ayers, 2009). Thus, in order to prevent lawsuits and ensure that female prison guards can work without witnessing masturbation, it is justified to ban masturbation (Cusack, 2014). Prison staffers have also focused on the concern in popular media sources over incarcerated people masturbating in sight of female correctional staff as a justification for these bans (e.g., Dold, 2017).

\section{Rape Prosecution}

It is very challenging to prosecute rape in U.S. prisons, because rape is conflated with prostitution and trading sex for "safety" (Money \& Bohmer, 1980). As a result, any amount of evidence can be critical in these cases in order to bring prison rapists to justice. Cusack (2014) contends that a ban on prison masturbation is justified because it can make any semen emission found within a prison reliable physical evidence in the prosecution of rape. To account for semen emissions made as a result of nocturnal emissions, she argues that incarcerated people should report all of their nocturnal emissions to correctional officers.

\section{Rehabilitation}

Finally, Cusack (2014) also argues that masturbation can cause depression, loss of energy, hair loss, and vision loss. To support these claims, Cusack (2014) cites two non-peer reviewed articles, one of which does not actually discuss several of these supposed harms (Witt, 2013), and the second of which seems to have been removed from the Psychology Today website (Robinson, 2010). These arguments echo similar arguments from the mid-1800s, claiming masturbation causes blindness and mental disorders, used to justify the prohibition of sexual expression in prisons of the time as well (Janofsky, 2004). Similarly, she argues that incarcerated people will use masturbation to avoid having to think about what they have done, and that masturbation is counterproductive to the work and energy of rehabilitating. Thus, she argues, because part of the goal of prison is to rehabilitate incarcerated people, and masturbation is counterproductive to that goal and harmful, prisons are justified in banning masturbation.

\section{Does the Policy Work?}

Each of the five justifications for the ban on masturbation fails to provide a good reason to defend the ban, largely because the ban on masturbation has not been effective in achieving its goals. To begin, incarcerated people's high rates of STIs are attributed to sex between incarcerated persons (Center for Disease Control, 2015), rather than accidental infection from masturbation. The impact of masturbation, if it spreads HIV at all, seems very minimal in 
comparison with the effect of prison sex and prison rape (Potter \& Rosky, 2014). If the primary goal of the ban on masturbation is to prevent the spread of STIs, but unintentionally increases the likelihood of prison rape (as I will argue below), banning masturbation could actually be increasing the rate of STI transmission, rather than preventing it Instead, other policies such as providing condoms to incarcerated people may be a more promising alternative to achieve this goal (Sylla et al., 2010).

Female prison guards also continue to be subjected to incarcerated men intentionally masturbating in their sight, despite the ban. While this is certainly a serious problem, and the proposed alternative policy in this article tries to protect employees such as female correctional officers from these forms of sexual harassment, simply banning masturbation by incarcerated people may not be an effective strategy. For example, past research outside of correctional settings has found that sexual aggression is predicted by sexual frustration and dissatisfaction (Kanin, 1983). It is possible that, if the ban is leading to more sexual frustration among incarcerated men who may not have an outlet for their sexual urges, the ban may unintentionally lead to increases in impulsive acts of harassment against female staff.

Cusack’s (2014) suggestion to require all incarcerated men to report all of their nocturnal semen emissions to correctional officers does not appear to have been taken up by any prison (perhaps because doing so would be cumbersome, dehumanizing, and engender substantial resistance from incarcerated people). However, even if this suggestion were taken up, it still rests on the flawed assumption that all semen outside of nocturnal emissions would be evidence of rape. If any semen outside of a nocturnal emission was considered evidence of rape, and most incarcerated men do masturbate, many of these acts of masturbation could be wrongly construed as rape.

Additionally, rather than creating order and preventing conflict between incarcerated people by banning masturbation, incarcerated people seem to be coordinating with one another to hide all sexual acts from prison guards, especially among incarcerated men (Vidal, 2014). This often involves one cellmate acting as a lookout for guards, called "bussing” in some prisons, while the other cellmate engages in sex or masturbation. Rather than fostering order, the ban fosters the coordinated subversion of order within prisons by encouraging incarcerated people to work together to thwart prison officials' enforcement of bans on any form of sexual expression.

Finally, if the goal of banning masturbation in prison is to prevent recidivism, especially among sex offenders, the ban is not supported by social science. A randomized experimental trial conducted at the University of Toronto found that people with pedophilic disorder who were assigned to refrain from masturbating for one month were no different in their levels of pedophilic fantasies than those who did not refrain (Rudin-Brown et al., 1996). Only a single participant agreed that prohibiting masturbation was helpful to their recovery, and many participants simply were not able to refrain from masturbating for a full month. Similarly, banning masturbation prevents other techniques that may be valuable in the treatment of sex offenders, such as helping incarcerated people learn about healthy sexual practices and habits (B. Smith, 2006). Though Cusack (2014) claims that masturbation reduces rehabilitation, she uses a blog post account of a single incarcerated person in prison to support her argument (Goad, 2013). There does not seem to be good evidence to support that claim. 


\section{Unintended Consequences}

In addition to not achieving the goals that the ban on prison masturbation was intended to reach, the ban may also lead to serious unintended consequences for the wellbeing and safety of incarcerated people. While it is the case that nearly all incarcerated men masturbate, the exact rate of masturbation is unknown, so it is challenging to know the exact effect of the ban. However, presumably, given the serious punitive consequences if an incarcerated person is caught, as well as the lack of private space within prisons, it is reasonable to assume that incarcerated people masturbate less frequently than they would if the ban was not in place. This section will discuss the potential negative consequences of banning masturbation under the assumption that the policy does in fact reduce masturbation among incarcerated people. ${ }^{1}$

\section{Violence and Rape}

Over the last two decades, behavioral endocrinology has come to better understand the neurological basis for impulsivity and sexual violence. It does seem to be the case that higher testosterone levels are associated with higher sexual motivation and that changes in testosterone levels play a more significant role in affecting sexual motivation than the absolute level of testosterone (Sherwin, 2013). Higher testosterone levels and aggression-impulsivity scores are found among convicted male rapists than among the general population of men (Giotakos et al., 2003). And for younger sex offenders, higher levels of testosterone were found in violent rapists than in non-violent rapists (Rada, 1983). Additionally, lower levels of serotonin-producing activities have been pointed out as a potential cause of impulsivity (Giotakos et al., 2003).

Masturbation is an activity that both tends to lower receptivity to testosterone, as well as release serotonin to end an orgasm, creating a subjective feeling of sexual satiety and preventing immediate sexual arousal following orgasm in men (Corona et al., 2009; for a relevant study on male rates, see Phillips-Farfán, Lemus, \& Fernández-Guasti, 2007) While one early study found heightened levels of testosterone immediately after masturbating (Purvis et al., 1976) and returning to normal shortly thereafter, a more relevant study found significantly heightened levels of testosterone in males who had avoided masturbating for three weeks (Exton et al., 2001). In other words, banning masturbation increases testosterone, which may be associated with higher rates of violence, impulsivity, and rape. This may be amplified by a lack of masturbation, leading to men producing lower levels of serotonin. Thus, the endocrinological

\footnotetext{
${ }^{1}$ If, alternatively, the ban on masturbation has no effect on the rate of actual masturbation, then the ban should be removed on its face, because it would be punishing people while having no effect on the behavior it intends to curb. One might respond to this claim by emphasizing a retributivist approach to incarceration, such as hypothetically claiming, "even if the policy does not reduce masturbation, it is still a good policy because it punishes people, and people are in prison to be punished; that is the point of prison." However, this approach would be flawed on several grounds. First, such a policy would be arbitrary. It is not clear why this particular form of recreation (masturbation) ought to be the target for punishment, as opposed to any other form of recreation (such as physical exercise, watching television, or reading), which are not routinely banned in prisons, if the purpose of prison is simply to punish recreation. Second, and more importantly, maintaining heavily punitive policies toward incarcerated people is associated with dehumanization and abuse of incarcerated people (Haney \& Zimbardo, 2009). Suggesting an ineffective policy should remain on the books simply by virtue of it allowing the prison to punish people simply sets the stage for justifying any harmful treatment as punishment, leading to the unjust abuse and dehumanization of incarcerated people.
} 
evidence seems to at least tentatively support the claim that banning masturbation increases impulsive, violent sexual behavior among incarcerated people.

\section{Exploitation by Guards}

Like Angela Harris, the guard who allegedly threatened an incarcerated person in solitary confinement if he did not strip and masturbate for her entertainment, the ban on prison masturbation might allow prison staff to exploit incarcerated people by threatening them with false reports of masturbation (Boxer $X v$. Harris, 2006). Sexual victimization of incarcerated people is rampant and increasing, with allegations of sexual victimization increasing by $20 \%$ from 2005 to 2011, and half of those allegations by incarcerated people against guards (Beck et al., 2014). Interestingly, in prisons (as opposed to jails) most staff-on-inmate sexual violence is perpetrated by female guards against incarcerated men (Beck \& Harrison, 2006). These statistics are, unfortunately, the only situations we know about because they were reported to correctional authorities. It is plausible that Boxer's case was not an isolated incident, and other incarcerated people have been similarly threatened and complied, without reporting or attempting a lawsuit. The ban on masturbation provides a unique opportunity for exploitation because unlike other wrongful behavior in prison, like drug use, violence, or theft, masturbation requires no evidence to prove, and among those in solitary confinement, does not take place in the view of many other incarcerated people who might serve as counter-witnesses.

\section{Sex Offender Recidivism}

As highlighted in the previous section on rehabilitation, banning masturbation prevents incarcerated people, especially sex offenders, from developing skills for the healthy expression of sexuality or sexual relationships (B. Smith, 2006). Rather than learning "self-control" as the ban intends, sex offenders, like other offenders, may simply learn not to masturbate while guards are watching (Vidal, 2014). It is challenging to find empirical literature on this subject with confidence in its accuracy, likely because many sex offenders may feel afraid to admit they masturbate, worrying it could lead to being punished for violating the prison rules or being dealt some other harsher penalty reserved specifically for sex offenders, like their masturbation habits being used against them in a civil commitment hearing. A similar lack of information has been reported for the general prison population (McGaughey \& Tewksbury, 2002), but the concerns are probably more pronounced for sex offenders, given the sexual nature of their crimes.

\section{Insomnia}

Insomnia is a typical problem among incarcerated people in prison, which can lead to irritability, uncooperativeness, and health problems. Unfortunately, it is only partially remedied by drug treatment, assuming sleep-aid drugs are even available (Elger, 2003). Masturbation releases prolactin, a hormone heavily involved in feeling sleepy, though it releases less prolactin than intercourse (Brody \& Krüger, 2006; Roky et al., 1993; Spiegel et al., 1994). Masturbation often begins in adolescence for men, as a strategy to help them sleep (Marcus \& Francis, 1975). A sudden ban on that part of a typical nighttime sleep ritual might lead to insomnia, especially when first adjusting to prison, consistent with work showing that insomnia gets better over the first few weeks of entry into prison, but symptoms of insomnia remain at clinical levels, even 
when given sleeping medications to combat insomnia (Elger, 2003). However, part of the causes of drug-resistant insomnia within the prison-setting might be directly the result of not being able to masturbate before sleeping, and the lack of prolactin release that results from that lack of masturbation. Thus, the prison ban on masturbation may be worsening insomnia among incarcerated people.

\section{Stress}

Many people have reported orgasms and masturbation as a subjectively stress-relieving experience (Meston \& Buss, 2007; Vance \& Wagner, 1976). Shortly following orgasm, blood pressure drops over the course of about ten minutes, which may explain some of the feeling of relaxation (Xue-Rui et al., 2008). Prison can be an extremely stressful experience, and incarceration-related stress is associated with serious negative health impacts (Massoglia, 2008). If the ban on prison masturbation is preventing people from engaging in an important stressrelief activity like masturbation, it is possible that the ban is increasing stress and stress-related illnesses.

\section{Depression and Suicide}

In addition to preventing aggression, lower rates of serotonin have also been strongly linked to higher rates of depression and suicide risk (Coppen \& Doogan, 1988; Roy et al., 1990; Sheline et al., 1995; Stanley \& Mann, 1983; Van Praag, 1981). Because masturbation can release serotonin, masturbation might help alleviate some depressive symptomatology by increasing bloodstream endorphins (Denison et al., 1999), though it does not seem to have been tested in a controlled clinical trial yet. Suicide rates are high and increasing in prisons in the United States (Palmer \& Connelly, 2005). It is the leading cause of death in U.S. prisons (Suto, 2007). Masturbation may play an important protective role against depression and suicide among incarcerated people, while banning the practice might exacerbate these issues.

\section{Solitary Confinement}

Incarcerated people who are caught masturbating are frequently punished with solitary confinement in the United States, and the negative psychological effects of solitary confinement are often wrongly blamed on the incarcerated person's masturbation (B. Smith, 2006). Some incarcerated people have even reported that being in solitary confinement has destroyed their desire to masturbate, as a result of such severe sensory deprivation (Shalev, 2008). A particularly illustrative quote from an incarcerated person reports:

The lethargy of months that add up to years in a cell, alone, entwines itself about every "physical" activity of the living body and strangles it slowly to death, the horrible decay of the truly living death.... You no longer masturbate; you can call forth no vision of eroticism in any form... time descends in your cell like the lid of a coffin in which you lie and watch it as it slowly closes over you. (Abbott, 1981, p. 44)

Solitary confinement results in very serious mental and physical health consequences for incarcerated people, especially since many of the people sent to solitary confinement for 
masturbating in sight of a guard have mental illnesses that also make it difficult for them to control their masturbation (Haney \& Lynch, 1997; Metzner \& Fellner, 2010; P. S. Smith, 2006). Because the ban on the masturbation of incarcerated people increases solitary confinement, it is may also be increasing severe mental and physical health deterioration for incarcerated people.

\section{Alternative Policy}

Given all of the harms of the ban on prison masturbation, as well as the failure of the ban to achieve its goals, this section will provide a two-prong alternative policy proposal in order to alleviate the worst effects of the ban on prison masturbation without jeopardizing the security or orderly functioning of the prison environment.

\section{Prong 1: Allowing Incarcerated People to Masturbate Under Specific Circumstances}

Allowing incarcerated people to masturbate would help potentially alleviate many of the unintended consequences brought about by the ban on prison masturbation. However, simply allowing incarcerated people to masturbate whenever they want would likely increase the experience of hostile work environments among female prison guards, as well as not teaching those with mental disabilities and sex offenders healthy ways to express sexuality. As an alternative to outright banning masturbation, allowing masturbation within specific conditions seems to be a good compromise. The easiest of these conditions to implement would be in prison settings that already afford incarcerated people spaces with a modicum of privacy. For example, in the relatively small number of prisons that already have enclosed stall doors between toilets, or enclosed shower cubicles, explicitly allowing incarcerated people to masturbate in these appropriate places is an easy way to allow prison masturbation without jeopardizing security or creating additional costs.

Alternatively, for prisons that have rooms for conjugal visits (once again, a small number of contemporary prisons), allowing those rooms to be used by incarcerated people for masturbation on a semi-regular basis (perhaps once every two weeks) would allow them to have their sexual needs met, without having to create any new security procedures or create any new facilities. Prison officials can simply employ the same security protocol they currently use for conjugal visiting.

Finally, for the majority of prisons that do not already have those options available, I would suggest allowing incarcerated people to masturbate within a very specific set of conditions, all of which must be met: (a) They must be alone in their own bed, (b) The lights in the room must be turned off, (c) It must be only be between the hours of 9 p.m. and 5 a.m., (d) The incarcerated person's genitals must be completely covered by a blanket, (e) The ejaculate must be expelled into a wad of toilet paper or tissue paper, (f) The tissue paper must be disposed of or flushed in a toilet before leaving their cell the following morning (for cells that have toilets), and (g) The incarcerated person must masturbate quietly enough to not disturb other nearby incarcerated people. These guidelines would help incarcerated people to have their sexual needs met and align with how many incarcerated men already practice masturbation but provide restrictions to protect female prison guards from being subjected to a hostile work environment as a result of an incarcerated person unintentionally masturbating in their line of sight. 


\section{Prong 2: Alternative Punishment Methods}

While solitary confinement is justified in the most extreme cases, such as preventing a violent act by an incarcerated person against another incarcerated person, or isolating an incarcerated person who is severely emotionally unstable for a short period of time, it is never justified in response to a person getting caught masturbating, an act which nearly all incarcerated men engage in. Instead, alternative punishment methods should be employed for masturbating outside of the outlined guidelines, such as loss of privileges and loss of access to the canteen. These mechanisms can still be a meaningful punishment for inappropriate masturbation, especially if the incarcerated person has alternative sexual outlets that are appropriate.

\section{Advantages of the Proposed Alternative Policy}

This policy attempts to be as realistic and non-disruptive as possible, so it can be applied to a variety of prison settings without much effort. It can potentially help reduce publicly masturbating as a form of sexual harassment, and uses facilities and policies already in place, without incurring significant additional costs to the prisons. It allows incarcerated people to masturbate more frequently, comfortably, responsibly and safely, alleviating some stress, some depressive symptoms, insomnia, and potentially leading to lower rates of suicide, rape, and violence. It may even curb a small portion of the leverage that a minority of guards have used to exploit incarcerated people's fears of being punished with solitary confinement for masturbating.

\section{Potential Objections}

There are several potential objections that I anticipate to this proposal. First, some might worry that the proposal would prevent incarcerated people from developing self-control, allowing them to satisfy their sexual desires when they should otherwise be repressing them. While I think I have sufficiently demonstrated that there are greater harms to attempting to repress masturbation completely, I will assume for a moment that those arguments have not been effective. Even so, incarcerated people are still learning self-control by learning where and when it is appropriate to masturbate, especially for sex offenders and the mentally ill, who may have trouble learning those skills when masturbation is banned in all contexts.

Another objection might contend that it is unhygienic, given that semen can spread STIs. However, if the semen is ejaculated in a shower or into a toilet, then the STI risk is nonexistent, as the fluid is sent down a drain. Likewise, if it is contained in a wad of toilet paper, and then flushed, the STI risk is also non-existent, especially since tiny drops of loose semen dry quickly and dried semen poses very little transmission risk (Public Health Agency of Canada, 2011). Finally, some might be concerned that allowing incarcerated people to masturbate constitutes a security risk, as a violent incarcerated person could try to craft a weapon under a blanket while feigning that they are masturbating. However, I will contend that this is not a unique risk under the newly proposed policy. Currently, a violent incarcerated person could try to craft a weapon under a blanket and simply stop moving while a guard walks by. A similar security risk is involved in both cases, and standard prison practices to prevent incarcerated people from acquiring the materials to craft a weapon should still be followed. 
Alternatively, the proposed policies might have quite different objections for prison reform and prison abolition advocates. For example, one might argue that allowing incarcerated people to masturbate under controlled circumstances will only generate another unjust mechanism of control and oppression. Instead, an alternative proposal should allow any incarcerated person to masturbate, and remove any power for correctional staff to control the incarcerated person's sexual expression. My response is that such a proposal is simultaneously unrealistic given the current attitudes Americans maintain towards incarcerated people, and inconsiderate of the female correctional staff who would otherwise be subjected to a hostile work environment.

Others might argue that prisons ought to simply ban masturbation in front of correctional staff (which is the policy in several states) and instruct incarcerated people to take care not to masturbate in their view. Similarly, one might argue that female correctional staff could be protected by simply announcing their presence before entering a cell, just as is already done for other private spaces in most prisons, such as showers. As a result, they might contend that creating specific rules around when masturbation is appropriate would be unnecessary. However, there are several advantages to constructing specific rules around when and where an incarcerated person can masturbate, as opposed to simply where and when they cannot. First, without rules about how ejaculate is to be disposed of, unhygienic semen emissions could pose a threat to the health of other incarcerated people, such as masturbating into another incarcerated person's bed, or into a blanket that is then subsequently washed by an incarcerated person working in a laundry shortly after emission. Likewise, having to announce oneself to enter into a space in which a person's cell can be seen might work for some prison environments, especially cells that have opaque doors, but would not work well for environments in which cells do not have opaque doors, or in which surveillance cameras are utilized (as opposed to direct supervision).

Others who are critical of pornography (e.g., Dworkin, 1981; MacKinnon, 1993; MacKinnon \& Dworkin, 1997) might argue that allowing masturbation would lead to the legitimization of pornography use in prisons, contending that pornography use leads to harmful consequences like violence against women. This is not a position I agree with and has been criticized as needing to account for many other mediators and moderators (Malamuth \& Hald, 2016) or as wholly inaccurate (Fisher \& Grenier, 1994). However, even if these claims were accurate, my response would be to argue that the policy I advocate discourages pornography use. Whether it is in the shower or when the lights are off, the policies I propose make it more challenging to enjoy the use of pornography while masturbating within the confines of the policy. Thus, the policy would be unlikely to lead to a legitimization of pornography use.

Even if this alternative proposal is not convincing, states should, at the minimum, only prohibit masturbation when it is intentionally public, following the lead of the ten states who do have such policies, to avoid the worst outcomes of banning masturbation outright.

\section{Discussion and Future Directions}

The results of this systematic review indicate that most states maintain some policy that bans masturbation among incarcerated people. A review of the social science and 
endocrinological research indicates that these policies may be misguided. Further, the review found that some states have not made their policies regarding the masturbation of incarcerated people publicly available at all. This is troubling. By not making inmate handbooks public it is difficult for the public to weigh in on these issues or even be aware of how incarcerated people are being treated. Regardless of whether prisons change their masturbation policies, all prisons should make this information easily available to the public. A lawyer and a Freedom of Information Act Request should not be a prerequisite to knowing the rules that govern prisons, which should supposedly be accountable to the people.

The policy proposal articulated in this article seeks to provide an alternative strategy for addressing the challenges that masturbation can pose, while also not relying on overly punitive strategies for managing it. While the primary goal of this article is to articulate a workable, realistic policy for prisons to apply to masturbation, the academic nature of this article also lends itself to recommendations for further study. There seem to be three important directions that future studies considering masturbation in U.S. prisons should consider. First, more research needs to be conducted that includes questions about masturbation, since it is the most common and nearly universal sexual practice in male prisons in the United States. Four studies over the course of 30 years simply is not enough to draw very many useful conclusions. Second, researchers should consider opportunities to partner with prisons who are being sued by female prison guards for creating a hostile work environment and are looking to settle the case out of court. Promising the plaintiffs to bring in a researcher to help better understand the problem and work toward solutions might help to strengthen the settlement and prevent similar lawsuits in the future. More importantly, such research might prevent women from being subjected to symbolic gendered violence as part of their daily work experience. Third, researchers should potentially consider building off pioneering experimental research in prisons that are allowing incarcerated people to be sexual in limited ways, such as the study of the effects of condom vending machines on reducing STI transmission rates (e.g., Sylla et al., 2010).

\section{Conclusion}

Completely banning incarcerated people from masturbating has been a misguided effort to control their sexual drives, motivated by prevailing cultural sex-negativity and largely rooted in a desire to punish incarcerated people and deprive them of pleasure. The overly punitive impulses of prison administration in the United States have been substantially criticized as an unjust form of dehumanization (Hallsworth, 2000; Weill \& Haney, 2017). Instead of relying on punitive impulses, masturbation policy, like any other prison policy, should be based on the inferences and conclusions we can make from the empirical, medical, and scientific literature, and not based on political ideology or faith-based rhetoric.

Banning masturbation may lead to increased rates of violence, rape, depression, suicide, insomnia, exploitation by prison guards, solitary confinement, and stress among incarcerated people, with little to no benefit in exchange. Instead, thoughtful, responsible policies to help regulate masturbation, rather than simply banning it, should be employed by prisons to help incarcerated men handle their sexual needs appropriately. 


\section{References}

Abbott, J. H. (1981). In the belly of the beast: Letters from prison. New York: Random House

Alexander, M. (2010). The new Jim Crow: Mass incarceration in the age of colorblindness. New York: New Press

Americans United for Separation of Church and State v. Prison Fellowship Ministries, Inc., 509 F.3d 406 (2007)

Batty, D. (2007, July 26). Prisoner found guilty of masturbating in his cell. The Guardian. Retrieved from http://www.theguardian.com/world/2007/jul/26/usa .davidbatty6

Baumeister, R. F., Catanese, K. R., \& Vohs, K. D. (2001). Is there a gender difference in strength of sex drive? Theoretical views, conceptual distinctions, and a review of relevant evidence. Personality and Social Psychology Review, 5(3), 242-273. https://doi.org/10.1207/S15327957PSPR0503_5

Beck, A. J., \& Harrison, P. M. (2006). Sexual violence reported to correctional authorities, 2005. Retrieved from Bureau of Justice Statistics website: http://www.state.gov/documents/organization/1500 83.pdf

Beck, A. J., Rantala, R. R., \& Rexroat, J. (2014). Sexual victimization reported by adult correctional authorities, 2009-11. Retrieved from US Department of Justice website: http://www.bjs.gov/content/pub/pdf/svraca0911.pd $\mathrm{f}$

Bedard, L. E. (2011). How to help prevent deviant sexual behavior in prison. Retrieved March 4, 2016, from CorrectionsOne website: http://www.correctionsone.com/jailmanagement/articles/3592634-How-to-helpprevent-deviant-sexual-behavior-in-prison/

Boxer X v. Harris , 437 F.3d 1107 (11th Cir. 2006)

Brody, S., \& Krüger, T. H. C. (2006). The postorgasmic prolactin increase following intercourse is greater than following masturbation and suggests greater satiety. Biological Psychology, 71(3), 312315. https://doi.org/10.1016/j.biopsycho.2005.06.008

Camp, S. D., Klein-Saffran, J., Kwon, O. (Karl), Daggett, D. M., \& Joseph, V. (2006). An exploration into participation in a faith-based prison program. Retrieved from https://www.bop.gov/resources/research_projects/p ublished_reports/gen_program_eval/volunteer_cpp. pdf
Center for Disease Control. (2015). HIV among incarcerated populations. Retrieved March 7, 2016, from Center for Disease Control website: http://www.cdc.gov/hiv/group/correctional.html

Coker, M. (2014). Common sense about common decency: Promoting a new standard for guard-oninmate sexual abuse under the Eighth Amendment. Virginia Law Review, 100, 437

Cooperman, A. (2006). Spiritual prison program ruled unconstitutional / Bush's faith-based initiative supports similar projects. SFGate. Retrieved from http://www.sfgate.com/news/article/Spiritualprison-program-ruled-unconstitutional2495543.php

Coppen, A. J., \& Doogan, D. P. (1988). Serotonin and its place in the pathogenesis of depression. Journal of Clinical Psychiatry. Presented at the Symposium: Serotonin in behavioral disorders (1987, Zurich, Switzerland). Retrieved from http://psycnet.apa.org/psycinfo/1989-19078-001

Corona, G., Ricca, V., Bandini, E., Mannucci, E., Lotti, F., Boddi, V., ... Maggi, M. (2009). Selective serotonin reuptake inhibitor-induced sexual dysfunction. Journal of Sexual Medicine, 6(5), 1259-1269. http://dx.doi.org.oca.ucsc.edu/10.1111/j.17436109.2009.01248.x

Crockett, C. E. (2012). A murder of crows: America's raucous right-wing. Xlibris Corporation

Cusack, C. M. (2014). No stroking in the pokey: Promulgating penological policies prohibiting masturbation among inmate populations. Journal of Law \& Social Deviance, 7, 80

Denison, F. C., Grant, V. E., Calder, A. A., \& Kelly, R. W. (1999). Seminal plasma components stimulate interleukin-8 and interleukin-10 release. Molecular Human Reproduction, 5(3), 220-226

Dold, K. (2017, January 6). Why it is illegal for prisoners to masturbate. Retrieved August 24, 2019, from Vice website: https://www.vice.com/en_us/article/ypvk7g/whyits-illegal-for-prisoners-to-masturbate

Dworkin, A. (1981). Pornography: Men possessing women. New York: Putnam

Elger, B. S. (2003). Does insomnia in prison improve with time? Prospective study among remanded prisoners using the Pittsburgh Sleep Quality Index. Medicine, Science, and the Law, 43(4), 334-344 
Exton, M. S., Krüger, T. H. C., Bursch, N., Haake, P., Knapp, W., Schedlowski, M., \& Hartmann, U. (2001). Endocrine response to masturbationinduced orgasm in healthy men following a 3-week sexual abstinence. World Journal of Urology, 19(5), 377-382. https://doi.org/10.1007/s003450100222

Fisher, W. A., \& Grenier, G. (1994). Violent pornography, antiwoman thoughts, and antiwoman acts: In search of reliable effects. The Journal of Sex Research, 31(1), 23-38. https://doi.org/10.1080/00224499409551727

Freitag v. Ayers., 468 F.3d 528 (2009)

Giotakos, O., Markianos, M., Vaidakis, N., \& Christodoulou, G. N. (2003). Aggression, impulsivity, plasma sex hormones, and biogenic amine turnover in a forensic population of rapists. Journal of Sex \& Marital Therapy, 29(3), 215-225. http://dx.doi.org.oca.ucsc.edu/10.1080/0092623039 0155113

Glaze, L. E., \& Kaeble, D. (2014). Correctional populations in the United States, 2013. Retrieved March 18, 2016, from Bureau of Justice Statistics website: http://www.bjs.gov/index.cfm?ty=pbdetail\&iid=51 77

Goad, J. (2013, July 29). Pleasuring myself in prison. Retrieved October 24, 2019, from Thought Catalog website: https://thoughtcatalog.com/jimgoad/2013/07/pleasuring-myself-in-prison/

Hallsworth, S. (2000). Rethinking the punitive turn: Economies of excess and the criminology of the other. Punishment \& Society, 2(2), 145-160. https://doi.org/10.1177/14624740022227926

Haney, C., \& Lynch, M. (1997). Regulating prisons of the future: A psychological analysis of supermax and solitary confinement. New York University Review of Law \& Social Change, 23, 477

Haney, C., \& Zimbardo, P. (1998). The past and future of U.S. prison policy: Twenty-five years after the Stanford prison experiment. American Psychologist, 53(7), 709-727

Haney, C., \& Zimbardo, P. G. (2009). Persistent dispositionalism in interactionist clothing: Fundamental attribution error in explaining prison abuse. Personality and Social Psychology Bulletin, 35(6), 807-814. https://doi.org/10.1177/0146167208322864

Hensley, C., Tewksbury, R., \& Wright, J. (2001). Exploring the dynamics of masturbation and consensual same-sex activity within a male maximum security prison. Journal of Men's Studies, 10(1), 59.
Hsieh, H.F., \& Shannon, S. (2005). Three approaches to qualitative content analysis. Qualitative Health Research, 15, 1277-1288. https://doi.org/10.1177/1049732305276687

Janofsky, J. L. (2004). “There is no hope for the likes of me”: Eastern State Penitentiary, 1829-1856 (Ph.D., Temple University). Retrieved from https://search.proquest.com/docview/305131615/ab stract/672A6FB1671D4265PQ/1

Johns, D. M. (2012, January 10). Should prison inmates have the right to masturbate? Retrieved August 24, 2019, from Slate Magazine website: https://slate.com/technology/2012/01/shouldprison-inmates-have-the-right-to-masturbate.html

Kanin, E. J. (1983). Rape as a function of relative sexual frustration. Psychological Reports, 52(1), 133-134. https://doi.org/10.2466/pr0.1983.52.1.133

Kassebaum, G. (1972). Sex in prison: Violence, homosexuality, and intimidation are everyday occurrences. Sexual Behavior, 2(1), 39-45

Kinsey, A. C., Pomeroy, W. B., \& Martin, C. E. (1948). Sexual behavior in the human male. Philadelphia: W.B. Saunders Co

Kunzel, R. (2010). Criminal intimacy: Prison and the uneven history of modern American sexuality. Chicago, Ill.; Bristol: University of Chicago Press.

MacKinnon, C. A. (1993). Only words. Cambridge, Mass.: Harvard University Press

MacKinnon, C. A., \& Dworkin, A. (1997). In harm's way: The pornography civil rights hearings. Cambridge, Mass.: Harvard University Press

Malamuth, N. M., \& Hald, G. M. (2016). The confluence mediational model of sexual aggression. In The Wiley Handbook on the Theories, Assessment and Treatment of Sexual Offending (pp. 53-71). https://doi.org/10.1002/9781118574003.wattso003

Marcus, I. M., \& Francis, J. J. (1975). Masturbation: From infancy to senescence (1st ed.). New York, N.Y.: Intl Universities Pr Inc

Massoglia, M. (2008). Incarceration as exposure: The prison, infectious disease, and other stress-related illnesses. Journal of Health and Social Behavior, 49(1), 56-71. https://doi.org/10.1177/002214650804900105

McGaughey, D., \& Tewksbury, R. (2002). Masturbation. In C. Henseley (Ed.), Prison sex: Practice and policy. Boulder, Colo: Lynne Rienner

Meston, C. M., \& Buss, D. M. (2007). Why humans have sex. Archives of Sexual Behavior, 36(4), 477507. https://doi.org/10.1007/s10508-007-9175-2 
Metzner, J. L., \& Fellner, J. (2010). Solitary confinement and mental illness in U.S. prisons: A challenge for medical ethics. Journal of the American Academy of Psychiatry and the Law Online, 38(1), 104-108.

Money, J., \& Bohmer, C. (1980). Prison sexology: Two personal accounts of masturbation, homosexuality, and rape. The Journal of Sex Research, 16(3), 258266

Murphy, S. (2016). 'Whitey’ Bulger disciplined at Florida prison for sexual activity. Boston Globe. Retrieved from https://www.bostonglobe.com/metro/2016/02/25/w hitey-bulger-disciplined-florida-prison-for-sexualactivity/9HRWu5qzhGHv5K47OhfUGO/story.htm l

Palmer, E. J., \& Connelly, R. (2005). Depression, hopelessness and suicide ideation among vulnerable prisoners. Criminal Behaviour and Mental Health: CBMH, 15(3), 164-170. https://doi.org/10.1002/cbm.4

Phillips-Farfán, B. V., Lemus, A. E., \& FernándezGuasti, A. (2007). Increased estrogen receptor alpha immunoreactivity in the forebrain of sexually satiated rats. Hormones and Behavior, 51(3), 328334. https://doi.org/10.1016/j.yhbeh.2006.12.001

Potter, R. H., \& Rosky, J. (2014). Health issues. In C. D. Marcum \& T. L. Castle (Eds.), Sex in Prison: Myths and Realities (pp. 113-128). Lynne Rienner Publishers

Public Health Agency of Canada. (2011). Human immunodeficiency virus_Pathogen Safety Data Sheets. Retrieved from http://www.phacaspc.gc.ca/lab-bio/res/psds-ftss/hiv-vih-eng.php

Purvis, K., Landgren, B.M., Cekan, Z., \& Diczfalusy, E. (1976). Endocrine effects of masturbation in men. Journal of Endocrinology, 70(3), 439-444. https://doi.org/10.1677/joe.0.0700439

Rada, R. T. (1983). Plasma androgens in violent and nonviolent sex offenders. Bulletin of the American Academy of Psychiatry \& the Law, 11(2), 149-158

Robinson, M. (2010, January 11). Was the Cowardly Lion just masturbating too much? Retrieved from Psychology Today website: http://www.psychologytoday.com/blog/cupidspoisoned-arrow/201001/was-the-cowardly-lionjust-masturbating-too-much

Rodgers v. Ohio Dept. Of Rehab. \& Corr., 91 Ohio App.3d 567-569 (1993)

Roky, R., Valatx, J.L., \& Jouvet, M. (1993). Effect of prolactin on the sleep-wake cycle in the rat. Neuroscience Letters, 156(1), 117-120. https://doi.org/10.1016/0304-3940(93)90453-R
Rosewarne, L. (2014). Masturbation in pop culture: Screen, society, self. Lexington Books

Roy, A., Virkkunen, M., \& Linnoila, M. (1990). Serotonin in suicide, violence, and alcoholism. Retrieved from http://psycnet.apa.org/psycinfo/1990-98427-008

Rubin, A. T. (2015). Resistance or friction: Understanding the significance of prisoners' secondary adjustments. Theoretical Criminology, 19(1), 23-42. https://doi.org/10.1177/1362480614543320

Rudin-Brown, C. M., Traverso, G., \& Federoff, P. (1996). Masturbation prohibition in sex offenders: A crossover study. Archives of Sexual Behavior, 25(4), 397-408. https://doi.org/10.1007/BF02437582

Shalev, S. (2008). A sourcebook on solitary confinement. Retrieved from http://solitaryconfinement.org/uploads/sourcebook _02.pdf

Sheline, Y. I., Bardgett, M. E., Jackson, J. L., Newcomer, J. W., \& Csernansky, J. G. (1995). Platelet serotonin markers and depressive symptomatology. Biological Psychiatry, 37(7), 442-447. https://doi.org/10.1016/00063223(94)00160-5

Sherwin, B. B. (2013). A comparative analysis of the role of androgen in human male and female sexual behavior: Behavioral specificity, critical thresholds, and sensitivity. Psychobiology, 16(4), 416-425. https://doi.org/10.3758/BF03327339

Smith, B. (2006). Analyzing prison sex: Reconciling self-expression with safety. Human Rights Brief, 13(3), 17

Smith, P. S. (2006). The effects of solitary confinement on prison inmates: A brief history and review of the literature. Crime and Justice, 34

Soble, A. (1997). Masturbation. In A. Soble (Ed.), The philosophy of sex: Contemporary readings (Third edition). Lanham: Rowman \& Littlefield

Spiegel, K., Follenius, M., Simon, C., Saini, J., Ehrhart, J., \& Bradenberger, G. (1994). Prolactin secretion and sleep. Sleep, 17(1), 20-27

Stanley, M., \& Mann, J. J. (1983). Increased serotonin2 binding sites in frontal cortext of suicide victims. The Lancet, 321(8318), 214-216. https://doi.org/10.1016/S0140-6736(83)92590-4

Stephens, W. (2015). Disciplinary rules and procedures for offenders. Retrieved from https://www.tdcj.state.tx.us/documents/cid/Discipli nary_Rules_and_Procedures_for_Offenders_Englis h.pdf 
Suto, I. (2007). Inmates who attempted suicide in prison: A Qualitative Study (Dissertation, Pacific University). Retrieved from http://commons.pacificu.edu/cgi/viewcontent.cgi?a rticle $=1061 \&$ context $=$ spp

Sykes, G.. (1958). The society of captives: A study of a maximum security prison. Princeton, NJ: Princeton University Press

Sylla, M., Harawa, N., \& Grinstead Reznick, O. (2010). The first condom machine in a US jail: The challenge of harm reduction in a law and order environment. American Journal of Public Health, 100(6), 982-985 https://doi.org/10.2105/AJPH.2009.172452

Tewksbury, R. (1989). Measures of sexual behavior in an Ohio prison. Sociology and Social Research, 74(1), 34-39

Van Praag, H. M. (1981). Management of depression with serotonin precursors. Biological Psychiatry. Retrieved from http://psycnet.apa.org/psycinfo/1981-33357-001

Vance, E. B., \& Wagner, N. N. (1976). Written descriptions of orgasm: A study of sex differences. Archives of Sexual Behavior, 5(1), 87-98. https://doi.org/10.1007/BF01542242
Vidal, A. (2014, February 26). Women prisoners: Sex in prison is commonplace, the male inmates just hide it more than girls. Retrieved March 18, 2016, from http://www.telegraph.co.uk/women/womenspolitics/10662145/Women-prisoners-Sex-inprison-is-commonplace-the-male-inmates-justhide-it-more-than-girls.html

Weill, J., \& Haney, C. (2017). Mechanisms of moral disengagement and prisoner abuse. Analyses of Social Issues and Public Policy, 17(1), 286-318. https://doi.org/10.1111/asap.12142

Witt, E. (2013, April 12). Why men are quitting masturbation. New York Magazine. Retrieved from http://nymag.com/news/features/anti-masturbation2013-4/

Wooden, W. S., \& Parker, J. (1982). Men behind bars: Sexual exploitation in prison. New York: Plenum Press

Xue-Rui, T., Ying, L., Da-Zhong, Y., \& Xiao-Jun, C. (2008). Changes of blood pressure and heart rate during sexual activity in healthy adults. Blood Pressure Monitoring, 13(4), 211-217. https://doi.org/10.1097/MBP.0b013e3283057a71 